\title{
HL-A Frequencies in Patients with Multiple Sclerosis*
}

\author{
D. W. PATY, H. MERVART, B. CAMPLING, C. G. RAND AND C. R. STILleR
}

SUMMARY: The histocompatibility antigens $(H L-A)$ have been determined in 100 multiple sclerosis (M.S.) patients and 143 randomly selected controls. In the M.S. group there was a statistically significant increase in the frequency of $H L-A 7$ and $W 18$ with an insignificant increase in $H L-A 3$. The variance from normal $H L-A$ patterns in the M.S. population may play some role in establishing the substrate for this disease. Studies in experimental animals have shown that susceptibility to autoimmune disease and to virus infection is linked to the major histocompatibility locus. This has interesting implications for both the "slow virus" and the "autoimmune" theories of the etiology of multiple sclerosis.

RESUME: Les antigènes d'histocompatibilité $(H L-A)$ furent déterminés chez 100 patients atteints de Sclérose en Plaque (S.E.P.) et chez 143 contrôles choisis au hasard. Dans le groupe de malades porteurs de S.E.P., il y avait une augmentation statistiquement significative de la fréquence de $H L-A 7$ et $W 18$ et une augmentation non significative de $H L-A$ 3. La variation des échantillons normaux $H L-A$ dans la population porteuse de S.E.P. peut jouer un rôle dans l'établissement du substrat de cette maladie. Les études chez les animaux expérimentaux ont montré que la susceptibilité à la maladie autoimmune et à l'infection virale est reliée au facteur majeur d'histocompatibilité. Ceci a des implications intéressantes concernant les deux théories dans l'étiologie de la sclérose en plagué, soit celle du "virus lent" et celle d'une maladie autoimmune.

From the Departments of Clinical Neurological Sciences. Epidemiology and Preventive Medicine, and Medicine, The University of Western Ontario, London, Canada.

* This material was presented in part at the Royal College of Physicians and Surgeons (Canada) Meeting in Montreal, January 25, 1974.

Reprint requests to Dr. D. W. Paty, University Hospital, 339 Windermere Road, London, Ontario N6G 2K3, Canada.
Study of the genetic control of the immune response in experimental animals has shown that the response to viral infection (Lilly, 1966), humoral and delayed hypersensitivity (McDevitt and Benacerraf, 1969), and the response to induction of autoimmune disease (Vladutiu and Rose, 1971) are genetically determined and linked closely to the major histocompatibility locus.
Williams and Moore (1973) have found that the susceptibility to production of Experimental Allergic Encephalomyelitis (EAE) in the backcross generations from the $F^{I}$ progeny of Brown Norway and Lewis rats is linked to the presences of the $\mathrm{H}-1^{1}$ allele. Lewis rats are homozygous for the $\mathrm{H}-\mathbf{1}^{1}$ allele and are $100 \%$ susceptible. Brown Norway rats are $\mathrm{H}-1$ homozygous and

TABLF I

COMPARISION OF OBSERVEN VALIES OF HL-A FREQIENCIES

Patients (m-100)

\begin{tabular}{|c|c|c|c|c|c|c|c|c|c|c|}
\hline \multicolumn{2}{|c|}{ AMULEN } & Pos. & Aleg. & YPos. & Pos. & Haleg. & gPos. & RLEF. IN & $x^{2}+$ & e \\
\hline HL-A & 1 & 35 & 65 & 35 & 40 & 103 & 28 & 7 & 1.0319 & M.S. \\
\hline HL-A & 2 & 42 & 58 & 42 & 70 & 73 & 49 & -7 & .8863 & M.S. \\
\hline HL-A & 3 & 36 & 64 & 36 & 35 & 108 & 24 & 12 & 3.2616 & $\langle .1\rangle .05$ \\
\hline$H L-A$ & 9 & 18 & 82 & 18 & 24 & 119 & 17 & 1 & .0048 & N.S. \\
\hline$H L-A$ & 10 & 12 & 88 & 12 & 12 & 131 & 8 & 4 & .5514 & N.S. \\
\hline$H L-A$ & 11 & 10 & 90 & 10 & 17 & 126 & 12 & -2 & .062 & N.S. \\
\hline$N$ & 28 & 8 & 92 & 8 & 10 & 133 & 7 & 1 & .0025 & M.S. \\
\hline$W$ & 32 & 8 & 92 & 8 & 12 & 131 & 8 & 0 & .0203 & N.S. \\
\hline$W$ & 29 & 5 & 95 & 5 & 9 & 134 & 6 & -1 & .0275 & N.S. \\
\hline$W$ & 30 & 6 & 94 & 6 & 11 & 152 & 8 & -2 & .0653 & N.S. \\
\hline$H L-A$ & 5 & 10 & 90 & 10 & 15 & 128 & 10 & 0 & .0074 & N.S. \\
\hline$H L-A$ & 7 & 46 & 54 & 46 & 34 & 109 & 24 & 22 & 12.2177 & $<, 001^{*}$ \\
\hline$H L-A$ & 8 & 26 & 74 & 26 & 31 & 112 & 22 & 4 & .3784 & N.S. \\
\hline$H L-A$ & 12 & 22 & 78 & 22 & 41 & 102 & $2^{a}$ & -7 & 1.0231 & M.S. \\
\hline$H L-A$ & 13 & 5 & 95 & 5 & 12 & 131 & 8 & -3 & .5875 & M.S. \\
\hline$W$ & 5 & 11 & 89 & 11 & 19 & 124 & 13 & -2 & .1006 & ii.s. \\
\hline$H$ & 27 & 9 & 91 & 9 & 6 & 137 & 4 & 5 & 1.5502 & N.S. \\
\hline$N$ & 14 & 6 & 94 & 6 & 10 & 133 & 7 & -1 & .0027 & M.S. \\
\hline$H$ & 15 & 6 & 94 & 6 & 17 & 126 & 12 & -5 & 1.783 & N.S. \\
\hline$W$ & 17 & 3 & 97 & 3 & 14 & 129 & 10 & -7 & 3.1988 & $\langle, 1\rangle, 05$ \\
\hline$H$ & 18 & 16 & 84 & 16 & 7 & 136 & 5 & 11 & 7.1319 & $\langle .01\rangle, 001^{\circ}$ \\
\hline$W$ & 10 & 12 & 88 & 12 & 22 & 121 & 15 & -3 & .3177 & N.S. \\
\hline$W$ & 21 & 7 & 93 & 7 & 4 & 139 & 3 & 4 & 1.5755 & N.S. \\
\hline$w$ & 16 & 2 & 98 & 2 & 7 & 136 & 5 & -3 & .6863 & N.S. \\
\hline W & 22 & 3 & 97 & 3 & 6 & 137 & 4 & -1 & .0191 & N.S. \\
\hline
\end{tabular}

+ Chi Souare - using a Yates correction factor for continuity,

- Considered statistically significant. 
$100 \%$ resistant. Susceptibility to EAE, both clinical and pathological, segregated for the most part with the H-11 allele. Gasser, et al (1973) havè had similar findings. These findings are important in the context of this paper since EAE is thought by some to be an experimental model for Multiple Sclerosis (M.S.).

These animal studies have been accompanied by a number of studies in humans examining the relationship between Human Histocompatibility Antigens (HL-A) and the prevalence of disease. These studies have brought to light a number of diseases, especially of the collagen disease variety, in which the HL-A antigen frequencies are at variance with the expected norm. (McDevitt and Bodmer, 1972, Schlosstein et al, 1973). Multiple sclerosis can now be added to this list. Several surveys of HL-A antigens in multiple sclerosis populations have been conducted in various parts of the world. The data from these surveys is noted in Table III. In this article we have reported HL-A antigen frequencies in a population of caucasian Canadian patients with multiple sclerosis.

\section{METHODS}

The patients were obtained from the rolls of the Multiple Sclerosis Clinic of University Hospital London, Ontario. Only patients meeting the diagnostic criteria of the Schumacher Panel (1965) for clinically definite multiple sclerosis have been tested. A total of 100 patients have been typed for HL-A antigens. One hundred and forty-three randomly selected healthy control subjects have also been tested. The results of our control series are similar to published control series.

The HL-A typing was done by a modified microdroplet lymphocyte cytotoxicity test (Mittal, et al. 1968), using the Terasaki $\mathrm{T}_{4}$ tissue typing tray.

\section{RESULTS}

The data from tissue typing 100 M.S. patients and 143 randomly selected controls are displayed in Table I. There is a statistically significant increase from the expected norm in the frequencies of
TABLE II

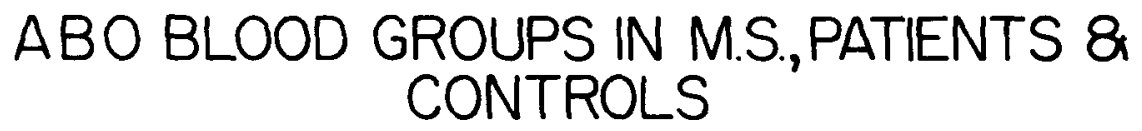

\begin{tabular}{|c|c|c|c|}
\hline GROUP & $\%$ POPULATION & $\%$ CONTROLS & $\%$ M.S. \\
\hline 0 & 46 & 46 & 41 \\
\hline A & 42 & 42 & 45 \\
\hline$B$ & 9 & 10 & 10 \\
\hline$A B$ & 3 & 3 & 4 \\
\hline
\end{tabular}

TABLE MI

Literature Summary of Frequencies of HL-A 7, 3, and W18 in Control and M.S. Populations

\begin{tabular}{|c|c|c|c|c|c|c|}
\hline \multirow[b]{2}{*}{$\begin{array}{l}\text { NUMBER OF PATIENTS } \\
\text { CONTROL / M.S. }\end{array}$} & \multicolumn{2}{|c|}{$H L-A: 7$} & \multicolumn{2}{|c|}{$H L-A: 3$} & \multicolumn{2}{|l|}{$W 18$} \\
\hline & $\stackrel{\%}{\%}$ CONTROL & $\begin{array}{l}\% \\
M S .\end{array}$ & CONTROL & $\begin{array}{l}\% \\
\text { M.S. }\end{array}$ & $\begin{array}{c}\% \\
\text { CONTROL }\end{array}$ & $\begin{array}{l}\% \\
\text { M.S. }\end{array}$ \\
\hline $\begin{array}{l}\text { PATY ef al } 143 / 100 \\
\text { CANADA }\end{array}$ & 24 & 46 & 25 & 36 & 5 & 16 \\
\hline $\begin{array}{l}\text { JERSILD et al } 958 / 135 \\
\text { DENMARK }\end{array}$ & 26 & 39 & 25 & 36 & 7 & 9 \\
\hline $\begin{array}{l}\text { NAITO et al } 871 / 94 \\
\text { USA. }\end{array}$ & 23 & 28 & 23 & 40 & 7 & 16 \\
\hline $\begin{array}{l}\text { BERTRAM ef al } 225 / 200 \\
\text { GERMANY }\end{array}$ & 31 & 35 & 27 & 37 & 9 & 14 \\
\hline $\begin{array}{l}\text { ARNASON et al 100/56 } \\
\text { U.S.A. }\end{array}$ & 21 & 39 & 23 & 43 & - & - \\
\hline
\end{tabular}

antigens HL-A $7 \quad(\mathrm{P}<0.001)$ and $\mathrm{W}-18(\mathrm{P}<0.01)$. There was a $12 \%$ increase in the occurrence of HL-A 3 in the M.S. group, but this failed to reach statistical significance. The occurrence of ABO blood groups (Table II) was as expected for the general population in both the control and M.S. groups.

\section{DISCUSSION}

Table III displays the data for several of the previously reported surveys of HL-A frequencies in M.S. patients. Our results are on the top line. The Danish study of Jersild et al. (1973) found increases in HL-A 7 and HL-A 3. The California study of Naito et al. (1972) found increases in HL-A 3 and W-18, while the German study of Bertrams, et al. (1972) found HL-A 3 was increased. Arnason, et al. (1974) from Boston have reported HL-A 3 and 7 as increased in M.S. patients. Jersild et al. (1973a) have also reported that there was a correlation between the presence of HL-A 3, 7, and W-18 and high serum measles antibody titre. In another paper Jersild et al. (1973b) have reported an additional study of a mixed lymphocyte determinant (LD-7a) that is linked to HL-A 7 and found in $70 \%$ of 28 randomly selected M.S. patients. Patients carrying this determinant had a significantly more rapid progression in clinical course than did LD-7a negative patients. Norris and Pietsch (1973) have recently reported that HL-A 3 and HL-A 7 are more frequently found in patients with paralytic poliomyelitis than in the normal. Animal studies have shown close linkage between the major histocompatibility locus and 
susceptibility to viral infections (Lilly, 1966) and to autoimmune disease, EAE (Williams and Moore, 1973).

Family and twin studies (MacKay and Myrianthopoulos, 1966) have shown there is an increased incidence of M.S. in families over the general population, but the concordance for monozygotic twins is no greater than for dizygotic twins. This is strong evidence against hereditary factors being primary in the etiology of M.S., but the HL-A frequencies suggest that there may be hereditary factors present that help determine susceptibility to acquiring M.S.

When taken together the following findings have interesting implications for both the "autoimmune" and the "virus" theories of the etiology of multiple sclerosis:

1. Certain histocompatibility antigens occur more frequently in the M.S. population than in the normal;

2. The occurrence of paralytic poliomyelitis may be associated with the presence of these same antigens;

3. The immune response locus and susceptibility to EAE in animals are both linked closely to the major histocompatibility locus.

Since the current theories for the etiology of M.S. include virus infection and related autoimmune phenomena, and both of these are influenced by genetic factors linked to the histocompatibility loci, it is important to pursue the relationship of the HL-A system to multiple sclerosis. We are in the process of relating the presence of HL-A antigens 3,7 , and $W-18$ to the clinical course of multiple sclerosis, to CSF composition and to measles antibody titres.

\section{REFERENCES}

ARNASON, B. G. W., FULLER, T. C., LEHRICH, J. R., and WRAY, S. H. (1974). Histocompatibility types and measles antibodies in multiple sclerosis and optic neuritis. Journal of the Neurological Sciences 22, 419-428.

BERTRAMS, J., and KUWERT, E. (1972). HL-A antigen frequencies in multiple sclerosis. Significant increase of HL-A 3 , HL-A 10 and W5, and decrease of HL-A 12. Eurp. Neurol. 7, 74-78.

GASSER, D. L., NEWLIN, C. M., PALM, J., GONATAS, N. K. (1973). Genetic control of susceptibility to experimental allergic encephalomyelitis in rats. Science 181 , 872-873.

JERSILD, C., SVEJGAARD, A., FOG, T., and AMMITZBOLL, T. (1973). HL-A antigens and diseases. I. multiple sclerosis. Tissue Antigens 3, 243-250.

JERSILD, C., AMMITZBOLL, T., CLAUSEN, J., and FOG, T. (1973a). Association between HL-A antigens and measles antibody in multiple sclerosis. The Lancet I, 151-152.

JERSILD, C., HANSEN, G. S., SVEJGAARD, A., FOG, T., THOMSEN, M., and DUPONT, B. (1973b). Histocompatibility determinants in multiple sclerosis, with special reference to clinical course. The Lancet IV, 1221-1226.

LILLY, F. (1966). The inheritance of susceptibility to the gross leukemia virus in mice. Genetics 53, 529-539.

MACKAY, R. P., and MYRIANTHOPOULOS, N. C. (1966). Multiple sclerosis in twins and their relatives, Final Report. Archives of Neurology (Chicago) $15,449-462$.

McDEVITT, H. O., and BENACERRAF, B. (1969). Genetic control of specific immune responses. Advances in Immunology, Vol. II, 32-74.

McDEVITT, H. O., and BODMER, W. F. (1972). Histocompatibility antigens, immune responsiveness and susceptibility to disease. The American Journal of Medicine 52, 1-8.

MITTAL, K. K., MICKEY, M, R., SINGAL, D. P., and TERASAKI, P. I. (1968). Serotyping for homotransplantation. XVIII. Refinement of microdroplet Lymphocytotoxicity test. Transplantation 6, 913-920.

MORRIS, P. J., and PIETSCH, M. C. (1973). A possible association between paralytic poliomyelitis and multiple sclerosis. The Lancet III, 847-848.

NAITO, S., NAMEROW, N., MICKEY, M. R., and TERASAKI, P. I. (1972). Multiple sclerosis: association with HL-A 3. Tissue Antigens 2, 1-4.

SCHUMACHER, G. A., BEEBE, G., KIBLER, R. F., KURLAND, L. T., KURTZKE, J. F., McDOWELL, F., NAGLER, B., SIBLEY, W. A., TOURTELLOTTE, W. W., and WILLMON, T. L. (1965). Problems of experimental trials of therapy in multiple sclerosis: Report by the panel on the evaluation of experimental trials of therapy in multiple sclerosis. Annals New York Academy of Sciences 122, 552-568.

VLADUTIU, A. O., and ROSE, N. R. (1971). Autoimmune murine thyroiditis relation to histocompatibility (H-2) type. Science $174,1137-1139$.

WILLIAMS, R. M., and MOORE, M. J. (1973). Linkage of susceptibility to experimental allergic encephalomyelitis to the major histocompatibility locus in the rat. The Journal of Experimental Medicine 138, 775-783. 